\title{
Lentokentän turvallisuuden rooleissa inminen, teknologia ja laki
}

Jonna Kielenniva, Lapin yliopisto, Matkailualan tutkimus- ja koulutusinstituutti (MTI)

Matkailun turvallisuus on yhä tärkeämpi aihe kaikille matkailijoille: ajatukset oman matkan aikana tapahtuvista vaaratilanteista lisääntyvät, kun ympärillä uutisoidaan erilaisista onnettomuuksista ja terrori-iskuista. Matkan turvallisuuden voidaan nähdä käsittävän koko matkan sen alkamisesta kotimatkaan asti. Vaikka lentomatkailu on ympäristövaikutustensa takia saanut osakseen negatiivista huomiota, se on yhä yksi merkittävimmistä matkustuskeinoista. Lentomatkailun ja lentokenttien turvallisuus on siis edelleen tärkeä tutkimusaihe. Viime vuosina sattuneet lento-onnettomuudet ja lentokenttiin kohdistuneet terrori-iskut ovat pitäneet aiheen ajankohtaisena myös julkisuudessa.

Lentokentän turvallisuutta onkin tutkittu useista eri näkökulmista. Aiemmissa tutkimuksissa on selvitetty lentokenttähenkilökunnan turvallisuuspäätöksiin vaikuttavia tekijöitä esimerkiksi uhkien arvioinnin näkökulmasta sekä sitä, voidaanko turvatarkastuksista tehdä entistäkin tehokkaampia (Kirschenbaum, 2015; Skorupski \& Uchroński, 2018). Myös matkustajien turvallisuuden kokemuksia lentokentällä on tutkittu (Beck, Rose \& Merkert, 2018). Lentokentät paikkoina muuttuvat koko ajan, kun teknologian kehittyessä saadaan käyttöön uusia ja tehokkaampia laitteita. Tämä tarjoaa myös uusia tutkimuksellisia näkökulmia.

Pro gradu -tutkimuksessani tarkastelin lentokentän turvallisuuden rakentumista toimijaverkkoteorian ja modaalisemiotiikan näkökulmasta. Toimijaverkkoteoriassa, jonka kehittäjinä tunnetaan Bruno Latour, Michel Callon ja John Law, korostetaan inhimillisten ja ei-inhimillisten toimijoiden yhteistoimintaa (Valkonen, Lehtonen \& Pyyhtinen, 2013, s. 218). Teoria kuvaa, kuinka eri toimijat kytkeytyvät toisiinsa ja tuottavat yhdessä sosiaalista todellisuutta. Semioottinen modaalisuus tutkii merkityksiä ja arvoja teksteissä (Sulkunen \& Törrönen, 1997, s. 73). Pyrkimyksenäni oli luoda teoreettinen kuvaus lentokentän turvallisuudesta, joka koostuu modaalisten eli haluavien, kykenevien, osaavien tai täytyvien toimijoiden luomasta toimijaverkosta. Tässä teoreettisessa mallinnuksessa käytin apuna omia kokemuksiani lentokentän turvallisuudesta sekä matkailijana että työntekijänä. Havaintoja olin tehnyt jo ennen tutkimusta kesällä 2018 lentokentällä työskennellessäni sekä aiemmin lentokentän kautta matkustaessani.

Lentokentän turvallisuuden verkosto rakentuu inhimillisistä ja ei-inhimillisistä toimijoista. Verkoston päätoimijoita ovat matkailija, turvallisuushenkilökunta, teknologia ja laki. Laki on 
verkoston vahvin toimija: muut toimijat toimivat lain mukaisesti ylläpitääkseen turvallisuutta. Lentokentän turvallisuutta ohjaa eri instituutioiden määrittämien säännöstöjen ja määräysten laaja joukko (Janssen, Sharpanskykh \& Curran, 2019, s. 142). Esimerkiksi Euroopan unionilla on lentoturvallisuutta koskevia määräyksiä (European Commission, 2019). Turvallisuushenkilökuntaa ovat esimerkiksi lentokentän turvatarkastajat, poliisit ja rajaviranomaiset. Teknologiaa taas ovat esimerkiksi läpivalaisulaite ja automaattinen rajatarkastuslaite. Lentokentän turvallisuuden ylläpitäminen on verkoston yhteinen tavoite. Sen lisäksi toimijoilla voi olla omia tavoitteita. Yhteisen toiminnan kautta jokainen verkoston toimija pääsee omaan tavoitteeseensa. Noudattamalla lakia matkailija pääsee matkalleen, turvallisuushenkilökunta kykenee ylläpitämään lentokentän turvallisuutta ja teknologia kykenee tunnistamaan laissa määritellyt kielletyt esineet.

Tutkimukseni tulokset osoittivat, että pragmaattisista modaalisuuksista lentokentän turvallisuudessa korostuvat täytymisen modaalisuudet (Sulkunen, 1997, s. 46). Matkailijan täytyminen ilmenee muun muassa turvatarkastuksen velvoitteena. Turvallisuushenkilökunnalle puolestaan täytyminen tarkoittaa turvallisuuden ylläpitämisen velvoitetta. Turvatarkastajan on esimerkiksi tehtävä matkailijalle turvatarkastus, jotta tämä pääsee etenemään matkallaan. Matkailija ja turvatarkastaja ovat näissä tilanteissa velvoitettuja toimimaan tietyllä tavalla, jotta turvallisuus voidaan ylläpitää. Matkailija on heikommassa asemassa kuin turvatarkastaja, sillä matkailijan on toimittava virkailijan pyyntöjen mukaisesti päästäkseen matkalle. Matkailijan asema voi kuitenkin esittäytyä vahvempana, mikäli sitä tarkastellaan haluamisen modaliteetin (Sulkunen, 1997, s. 46) kautta: kun matkailija päättää lähteä matkalle, hän haluaa tehdä turvatarkastuksen sen sijaan, että hänen täytyisi tehdä turvatarkastus.

Turvallisuus on vaikeasti määriteltävä käsite, koska esimerkiksi taustamme vaikuttavat turvallisuuden kokemuksiimme (Iivari, 2012, s. 20). Lisäksi normit ja kulttuuri vaikuttavat turvallisuustoimintojen hyväksymiseen (ICAO, 2013) - olemme esimerkiksi tottuneet kotimaassamme tiettyihin toimintatapoihin lentokentällä. Vaikka tutkimustulokset toivat ilmi teknologian vaikutuksen turvallisuuteen, turvallisuuden näkemyksemme ja kokemuksemme vaihtelevat hyvinkin paljon. Jotkut saattavat kokea teknologian vähentävän lentokentän turvallisuutta, koska he luottavat ihmisiin enemmän. Toisaalta jotkut voivat luottaa teknologiaan enemmän, koska ihmiset voivat tehdä päätöksiä esimerkiksi tunteiden pohjalta.

Tutkimukseni tulokset osoittavat, että teknologia on yhä enemmän läsnä elämässämme ja osa jokapäiväistä toimintaamme. Emme ole ihmisinä yksin ylläpitämässä ja kehittämässä esimerkiksi turvallisuutta, vaan turvallisuuteemme vaikuttavat tekijät ovat moniulotteisempia kuin aiemmin. Toimijaverkkoteoria tuo hyvin ilmi sen, kuinka me ihmiset emme nykyään yksin rakenna ja ylläpidä sitä sosiaalista todellisuutta, jossa elämme.

\section{Lähteet}

Beck, J. M., Rose, J. M. \& Merkert, R. (2018). Exploring perceived safety, privacy and distrust on air travel choice in the context of differing passenger screening procedures. Journal of Travel Research, 57, 495-512. https://doi.org/10.1177\%2F0047287517700316 
European Commission. (2019). European aviation safety rules. Haettu 24.08.2019 osoitteesta https://ec.europa.eu/transport/modes/air/safety/safety-rules_en

ICAO. (2013). Safety management manual (SMM) (Third edition). Haettu 20.08.2019 osoitteesta https://www.skybrary.aero/bookshelf/books/644.pdf

Iivari, P. (2012). Matkailun turvallisuus: Globaalit muutokset-paikalliset vaikutukset. Rovaniemen ammattikorkeakoulu.

Janssen, S., Sharpanskykh, A. \& Curran, R. (2019). Agent-based modelling and analysis of security and efficiency in airport terminals. Transportation Research Part C: Emerging Technologies, 100, 142-160. https://doi.org/10.1016/j.trc.2019.01.012

Kirschenbaum, A. (2015). The social foundations of airport security. Journal of Air Transport Management, 48, 34-41. https://doi.org/10.1016/j.jairtraman.2015.06.010

Skorupski, J. \& Uchroński, P. (2018). Evaluation of the effectiveness of an airport passenger and baggage security screening system. Journal of Air Transport Management, 66, 53-64. https://doi. org/10.1016/j.jairtraman.2017.10.006

Sulkunen, P. (1997). Todellisuuden ymmärrettävyys ja diskurssianalyysin rajat. Teoksessa P. Sulkunen \& J. Törrönen (toim.), Semioottisen sosiologian näkökulmia: Sosiaalisen todellisuuden rakentuminen ja ymmärrettävyys (s. 13-53). Helsinki: Gaudeamus.

Sulkunen, P. \& Törrönen, J. (1997). Arvot ja modaalisuus sosiaalisen todellisuuden rakentamisessa. Teoksessa P. Sulkunen \& J. Törrönen (toim.), Semioottisen sosiologian näkökulmia: Sosiaalisen todellisuuden rakentuminen ja ymmärrettävyys (s. 72-95). Helsinki: Gaudeamus.

Valkonen, J., Lehtonen, T.-K. \& Pyyhtinen, O. (2013). Sosiologista materiaalioppia. Sosiologia, 50, 217-221. 